\title{
Pembelajaran Tahfidz Al Qur'an dalam Penanaman Karakter Islami
}

\author{
Muhammad Shobirin, M. Pd \\ IAIN Kudus, Kudus, Indonesia \\ Muhammad_shobirin@iainkudus.ac.id
}

\begin{abstract}
Abstrak
Penelitian ini bertujuan untuk mengetahui langkah-langkah pendidikan karakter melalui program Tahfidz Al Qur'an SD I Nurul Qur'an Semarang, untuk mengidentifikasi karakter Islami siswa SD I Nurul Qur'an Semarang melalui program Tahfidz Al Qur'an. Penelitian ini menggunakan jenis penelitian deskriftif kualitatif dengan teknik analisis triagulasi data. Untuk mendapatkan informasi peneliti menggunakan teknik wawancara, observasi dan dokumentasi dengan subjek guru dan kepala sekolah. Berdasarkan hasil didapatkan: Langkah-langkah pendidikan karakter Islami melalui pembelajaran Tahfidz Al Qur'an SD I Nurul Qur'an Semarang; SD I Nurul Qur'an Semarang telah memberikan salah satu bentuk dan pola pendidikan karakter Islami dalam pembelajaran Tahfidz Al Qur'an yang memasukan 5 karakter yaitu: Religius, bersih, istiqomah, disiplin, dan sabar dalam pembelajaranya.Tujuan penelitian ini adalah 1.Untuk mengetahui langkah-langkah pendidikan karakter Islami dalam pembelajaran Tahfidz Al Qur'an. 2. Untuk mengetahui implementasi pendidikan karakter Islami dalam pembelajaran Tahfidz Al Qur'an
\end{abstract}

Kata Kunci : Pembelarajan Tahfidz, Karakter Islami.

\begin{abstract}
This study aims to determine the steps of character education through the Tahfidz Al Qur'an Elementary School I Nurul Qur'an Semarang, to identify the Islamic character of the Nurul Qur'an Elementary I Semarang students through the Tahfidz Al Qur'an program. This study uses a qualitative descriptive study with data triagulation analysis techniques. To obtain information the researchers used interview, observation and documentation techniques with the subject of the teacher and the principal. Based on the results obtained: Steps of Islamic character education through learning Tahfidz Al Qur'an Elementary School I Nurul Qur'an Semarang; Nurul Qur'an Elementary School Semarang has provided one form and pattern of Islamic character education in learning Tahfidz Al Qur'an which includes 5 characters: Religious, clean, istiqomah, discipline, and patience in the learning. The objectives of this study are 1. For know the steps of Islamic character education in learning Tahfidz Al Qur'an. 2. To find out the implementation of Islamic character education in learning Tahfidz Al Qur'an
\end{abstract} Keywords: Tahfidz Learning, Islamic Character. 


\section{A. Pendahuluan}

Manusia diciptakan Allah sebagai khalifah karena memiliki banyak anugrah yang dimiliki dan yang tidak dimiliki makhluk lain, hal itu menjadi keistimewaan dan menghantarkanya kepada kemuliaan dan kebahagiaan. Keistimewaan dari Allah yang diberikan kepada manusia adalah akal dengan akal manusia mampu mengendalikan perasaan mengontrol kemauan dan berfantasi sehingga membentuk karakter yang kuat dalam diri sebagai kontrol terhadap sesuatu yang dihadapi. Konsep Pendidikan karakter telah ada sejak zaman Rasulullah SAW. Terbukti dari perintah Allah memberikan tugas kepada Rasulullah untuk menyempurnakan akhlak bagi ummatNya.

Karakter itulah yang membedakan antara manusia dengan hewan. Manusia bisa disebut sebagai orang yang memiliki karakter kuat dan baik secara individual maupun sosial ketika mereka memiliki akhlak, moral, dan budi pekerti yang baik. Karakter dapat diperoleh dengan berbagai cara. Salah satu cara yang dapat digunakan untuk membentuk karakter ialah melalui pendidikan. Pendidik memiliki tanggung jawab untuk menanamkannya kepada peserta didik, baik melalui proses pembelajaran maupun di luar pembelajaran. (Zubaedi, 2001:1)

Pendidikan merupakan suatu pembinaan terhadap pembangunan bangsa secara keseluruhan yang mencakup semua aspek terutama pendidikan karakter. Saat ini pendidikan dituntut untuk dapat menemukan perannya sebagai basis dan benteng tangguh yang akan menjaga dan memperkokoh etika dan moral bangsa. Pendidikan merupakan suatu media sosialisasi nilai-nilai luhur, khususnya ajaran agama yang akan lebih efektif bila diberikan kepada anak (siswa) sejak sekolah dini (Muhtar, 2003: 14). Pendidikan pada dasarnya bertujuan untuk membentuk karakter peserta didik. Tujuan yang diharapkan dalam pendidikan tertuang dalam Undang- undang Nomor 20 Tahun 2003 tentang sistem pendidikan Nasional dalam pasal 3 yang isinya adalah:

Pendidikan nasional berfungsi mengembangkan dan membentuk watak serta peradaban bangsa yang bermartabat dalam rangka mencerdaskan kehidupan bangsa, bertujuan untuk berkembangnya potensi peserta didik agar menjadi manusia yang beriman dan bertakwa kepada Tuhan Yang Maha Esa, berakhlak mulia, sehat, berilmu, cakap, kreatif, mandiri, dan menjadi warga negara yang demokratis serta bertanggung jawab. Pemerintah melalui Kementerian Pendidikan Nasional sudah mencanangkan 


\section{QUALITY}

\section{Volume 6, Nomor 1, 2018: 16-30}

penerapan pendidikan karakter untuk semua tingkat pendidikan dari SD sampai Perguruan Tinggi. (Sri Narwani, 2011:1)

Pendidikan karakter bertujuan agar generasi muda bangsa memiliki kepribadian yang mulia serta memiliki bekal yang cukup untuk menjalani kehidupan dengan keadaan zaman yang semakin terbuka dan dinamis ini. Keadaan zaman tersebut sedikit banyak telah merubah cara hidup manusia, dengan mudahnya seseorang memperoleh informasi dari berbagai media sehingga peluang untuk mengikuti trend sangatlah besar. Sayangnya, perkembangan tersebut tidak hanya berdampak positif saja bagi masyarakat tetapi juga memberi dampak negatif pula terutama bagi generasi muda bangsa.

Banyak remaja yang kurang tahu tata krama terhadap orang tua dan guru. Mereka berani kepada orang tua, tidak menghormati guru, dan bertindak sesuka hati tanpa mempedulikan lingkungan sekitar.Kemajuan zaman dengan arus globalnya tersebut tidak mungkin bisa sampai menimbulkan bahaya yang akhirnya merusak kehidupan bangsa jika dari dalam diri generasi kita sudah tertanam iman yang kuat, iman yang menolak akan segala sesuatu yang bertentangan dengan keinginan dari dalam hatinya. Karakter yang sudah mengkristal inilah yang menjadi benteng bagi fikiran dan hati sehingga tidak mudah dikendalikan oleh nafsu yang hanya mementingkan kesenangan di dunia dan mengabaikan pertanggungajawaban di akhirat.

Pendidikan karakter menjadi modal utama dalam mensikapi problematika yang terjadi dimasyarakat sekarang ini seperti halnya maraknya kasus immoral (pelanggaran) yang terjadi merupakan bentuk rendahnya karakter yang dimiliki oleh masyarakat seperti hanlnya kebiasaan menyontek yang dilakukan peserta didik disaat tes, tawuran antar sekolah, prilaku tidak jujur, bolos sekolah, ini seolah-olah menjadi kebiasaan dan yang lazim terjadi dilingkungan sekolah serta menjadi salah satu kemunudran karakter masyarakat. Kebiasaan buruk tersebut tentunya tidak menjadi suatu hal yang patut dibanggakan, dengan demikian perlunya pendidikan karakter untuk mengurangi atau bahkan menghapus kebiasaan yang seharusnya tidak dilakukan.

Menurut Lickona (1992 :22) karakter merupakan sifat alami seseorang dalam merespon situasi secara bermoral. Sifat alami tersebut diimplementasikan dalam tindakan nyata melalui tingkah laku yang baik, jujur, bertanggung jawab, adil, menghormati orang lain, disiplin, dan karakter luhur lainnya. Sedangkan menurut Koesoema (2007 :53) 


\section{QUALITY}

\section{Volume 6, Nomor 1, 2018: 16-30}

istilah karakter dianggap sebagai ciri atau karakteristik atau gaya atau sifat dari diri seseorang yang bersumber dari bentukan-bentukan yang diterima dari lingkungan.

Menurut Kamus Besar Bahasa Indonesia (KBBI), karakter adalah sifat-sifat kejiwaan, akhlak, atau budi pekerti yang membedakan seseorang dari yang lain. Karakter juga bisa dipahami sebagai tabiat atau watak. Dengan demikian, orang yang berkarakter adalah orang yang memiliki karakter, mempunyai kepribadian, atau berwatak.

Berdasarkan pengertian tersebut, terdapat persamaan kata karakter. Karakter bisa disebut sebagai akhlak, budi pekerti, tabiat ataupun watak. Istilah-istilah tersebut memiliki makna yang sama, yaitu sikap atau perilaku yang muncul dari diri seseorang, yang membedakan seseorang dari orang lain. Sikap itu muncul secara cepat dan tanpa pemikiran panjang sebagai bentuk tanggapan terhadap situasi yang ada. Sikap tersebut meliputi perilaku jujur, adil, tanggung jawab, disiplin, ramah, dan lain sebagainya.

Mohamad Mustari (2011:1) menjelaskan dalam menghadapi penyimpangan remaja yang merusak karakter bangsa, landasan agama menjadi sangat penting untuk menyelesaikan masalah tersebut. Penanaman karakter Islami harus lebih ditekankan dalam penanaman karakter anak sehingga terciptanya karakter Islami pada anak tersebut. Karakter Islami ini sendiri merupakan karakter yang hubungannya dengan Tuhan.

Penanaman karakter sudah tentu penting untuk semua tingkat pendidikan, mulai sekolah dasar hingga perguruan tinggi. Penanaman karakter tidak hanya dilakukan melalui lembaga pendidikan formal, tetapi juga perlu ditanamkan semenjak anak berusia dini melalui pendidikan informal dalam keluarga dan lingkungan. Apabila karakter seseorang sudah terbentuk sejak usia dini, ketika dewasa tidak akan mudah berubah meski godaan atau rayuan datang begitu menggiurkan. Dengan adanya pendidikan karakter semenjak dini, diharapkan persoalan mendasar dalam pendidikan yang akhir-akhir ini sering menjadi keprihatinan bersama dapat diatasi. Pendidikan di Indonesia sangat diharapkan dapat manusia yang unggul, yakni para anak bangsa yang beriman, bertakwa, berakhlak mulia, mempunyai keahlian di bidangnya, dan berkarakter.

Seseorang dikatakan memiliki karakter Islami jika pikiran, perkataan, dan perbuatan seseorang sesuai dengan syariat agama (Islam). Dalam Islam sendiri seluruh perilaku dan kebiasaan seseorang harus berlandaskan pada Al Qur'an dan Sunnah. Karakter Islami dalam Islam bisa bersumber dari keteladanan Rasulullah 


\section{QUALITY}

Volume 6, Nomor 1, 2018: 16-30

dimana beliau memiliki 4 karakter yaitu shiddiq (jujur), amanah (dipercaya), tabligh (menyampaikan), dan fathanah (cerdas). Apabila peserta didik ditanamkan nilai-nilai Islami tersebut maka akan terbentuklah pribadi yang berkarakter Islami yang akan memperbaiki generasi bangsa dengan demikian peserta didik bukan hanya memiliki karakter baik saja akan tetapi juga memiliki landasan agama yang kuat dalam menjalankan kehidupannya. Dalam rangka pembentukan karakter Islami peserta didik, lembaga pendidikan dianggap memiliki peran penting untuk mencapai hal tersebut.

Sjarkawi Menjelaskan (2006:45) Manusia berkarakter tentu tidak bisa lahir dan tercipta dengan sendirinya. Proses pembentukan karakter tidak bisa dilakukan secara parsial. melainkan harus meliputi berbagai hal, integrative antara kehidupan jasmani dan rohani, holistic yang meliputi berbagai potensi manusia.

Melihat pentingnya penanaman karakter Islami pada anak, setiap sekolah memiliki cara sendiri dalam menyelesaikan problem untuk membentuk karakter anak. Dalam lembaga pendidikan karakter Islami peserta didik bisa dibentuk melalui pembelajaran Tahfidz Al Qur'an seperti yang dilakukan di SD Islam Nurul Qur'an Semarang. melalui pembelajaran Tahfidz Al Qur'an seorang guru akan lebih mudah menanamkan nilai-nilai Islam yang telah terkandung dalam Al Qur'an. Sehingga dalam proses menghafal Al Qur'an, peserta didik bukan hanya menghafal akan tetapi juga mengetahui makna atau isi yang terkandung sehingga bisa di aplikasikan dalam kehidupan yang nyata.

Bedasarkan latarbelakang masalah yang telah disebutkan maka penulis tertarik untuk meneliti tentang bagaimana implementasi pembelajaran Tahfidz Al Qur'an dalam pembentukan karakter Islami Peserta didik Objek penelitian di SD Islam Nurul Qur'an Semarang

\section{Pembahasan}

\section{Kajian Pustaka}

Penelitian mengenai Pembelajaran Tahfidz Al Qur'an dalam Penanaman Karakter Islami di SD Islam Nurul Qur'an Semarang berdasarkan Eksplorasi Peneliti, Terdapat beberapa hasil penelitian yang yang mempunyai relevansi dengan penelitian ini, diantaranya :

1. Ummi Kulsum dengan Judul : Implementasi Pembelajaran Hifzil Qur'an Dalam Pembentukan Karakter Relegius Peserta Dididk di MTs NU Miftahul Huda III Dawe Kudus Penelitian ini bertujuan 1) untuk mengetahui implementasi pembelajaran 
QUALITY

Volume 6, Nomor 1, 2018: 16-30

hifzil Qur'an di MTs NU Miftahul Huda III Lau Dawe Kudus tahun pelajaran 2018/2019, 2) untuk mengetahui pembentukan karakter religius peserta didik di MTs NU Miftahul Huda III Lau Dawe Kudus tahun pelajaran 2018/2019, 3) untuk mengetahui implementasi pembelajaran Hifzil Qur'an dalam pembentukan karakter religius peserta didik di MTs NU Miftahul Huda III Lau Dawe Kudus tahun pelajaran 2018/2019, dan 4) untuk mengetahui apa saja faktor pendukung dan penghambat implementasi pembelajaran Hifzil Qur'an dalam pembentukan karakter religius peserta didik di MTs NU Miftahul Huda III Lau Dawe Kudus tahun pelajaran 2018/2019. 


\section{QUALITY}

\section{Volume 6, Nomor 1, 2018: 16-30}

Hasil penelitian menunjukkan bahwa 1) Pelaksanaan pembelajaran hifzil Qur'an di MTs NU Miftahul Huda III Lau Dawe terdiri dari empat tahapan yaitu tahap pendahuluan (wudlu, berdoa, motivasi, dan memastika kesiapan); tahap pelaksanaan (binnador dan bilgoib), tahap evaluasi (non tes meliputi target surat dan tajwid serta makhorijul hurufnya), dan tahap tindak lanjut (follow up) meliputi remedial, pembelajaran Hifzil Qur'an dilakukan melalui inovasi "menghafal tanpa menghafal, 2) Pembentukan karakter religius peserta didik MTs NU Miftahul Huda III Lau Dawe melalui beberapa model yakni model motivasi, kisah, teladan, dan pembiasaan berupa kegiatan dan program di madrasah, 3) Guru Tahfiz membentuk karakter religius peserta didik dalam pembelajaran Hifzil Qur'an melalui model motivasi, model kisah, dan menjelaskan kandungan ayat Al-Qur'an, 4) Faktor penghambat dan faktor pendukung implementasi Hifzil Qur'an dalam pembentukan karakter religius peserta didik di MTs NU Miftahul Huda III Lau Dawe yaitu faktor penghambatnya meliputi: waktu, perbedaan tingkat kemampuan anak, suasana kelas tidak kondusif, lingkungan, perbedaan karakter anak, maksiat, dan HP. Sedangkan faktor pendukungnya meliputi: niat, motivasi, keluarga, tokoh agama.

2. Rochmatun Nafi'ah, Judul Penelitian : Efektifitas Program Tahfidz Al Qur'an Dalam Memperkuat Karakter Siswa di Madrasah Aliyah Negeri Lasem. Penelitian ini membahas tentang efektivitas program Tahfidz dalam memperkuat karakter siswa di Madrasah Aliyah Negeri Lasem. penelitian ini dimaksudkan untuk menjawab permasalahan: 1) bagaimana pelaksanaan program Tahfidz Al-Qur'an di Madrasah Aliyah Negeri Lasem 2) bagaimana karakter siswa yang mengikuti program Tahfidz Al Qur'an di Madrasah Aliyah Negeri Lasem 3) bagaimana efktifitas program Tahfidz Al Qur'an di Madrasah Aliyah Negeri Lasem. Dari hasil penelitian diketahui bahwa: pelaksanaan program Tahfidz yang dijalankan di Madrasah Aliyah negeri lasem adalah termasuk kategori baik, dan program ini merupakan kegiatan ekstrakurikuler yang dilaksanakan saat pembelajaran PAI, dengan target hafalan 1 tahun siswa hafal minimal 5 juz. waktu hafalan yaitu hari senin sampai jum'at. 


\section{Analisis Hasil}

\section{A. Implementasi Pembelajaran Tahfidz Al Qur'an di SD I Nurul Qur'an Semarang}

Pelaksanaan kegiatan pembelajaran adalah upaya yang dilakukan oleh pendidik untuk merealisasikan rancangan yang telah disusun baik. Karena itu pelaksanaan kegiatan pembelajaran yang menunjukkan penerapan langkah-langkah metode dan strategi kegiatan belajar mengajar Pada garis besarnya ada beberapa langkah yang dilakukan oleh pendidik dengan peserta didik dalam melaksanakan pembelajaran Tahfidz Al Qur'an diantaranya:

Langkah-langkah Pembelajaran Tahfidz Al Qur'an Kepala Sekolah dengan Wakakurikulum serta guru PAI membentuk Tim Tahfidz Al Qur'an (TTQ) setelah terbentuk Tim TTQ merumuskan panduan pengajaran Tahfidz Al Qur'an sekolah dan tim TTQ mengadakan sosialisasi panduan TTQ kepada seluruh guru TTQ, sekolah mengadakan pelatihan dan pembinaan kepada seluruh guru TTQ. Sekolah membentuk koordinator jenjang TTQ tingkatan kelas sekolah melibatkan wali murid untuk membantu mengawasi dan mendampingi putra-putrinya ketika belajar diluar sekolah dan melaporkanya kepada wali kelas masing-masing. Sekolah menyiapkan seluruh sarana dan prasarana penunjang proses penanaman pendidikan karakter Islami dalam pembelajaran Tahfidz Al Qur'an sekolah mengadakan pengawasan terhadap proses penanaman pendidikan karakter Islami dalam pembelajaran Tahfidz Al Qur'an melalui koordinator jenjang. Sekolah mengadakan evaluasi pelaksanaan penanaman pendidikan karakter Islami dalam pembelajaran Tahfidz Al Qur'an minimal 2 kali dalam setahun. Atau sesuai dengan kebutuhan.

Pembelajaran Tahfidz Al Qur'an dilaksanakan setiap pagi hari sebelum memasuki jam pelajaran pertama yakni jam 07.00- 07.40 WIB mulai hari Selasa sampai dengan hari Jumat untuk hari senin dipergunakan upacara bendera. Dalam menghafal Al Qur'an (juz 'amma atau juz 30), metode yang digunakan ialah metode klasikal dengan membaca dan menghafal berulang-ulang secara bersama-sama. Selain membaca, guru juga menuntun peserta didik. Peserta didik menirukan yang diucapkan oleh guru. Dengan menirukan, peserta didik tahu makhraj dan tajwid yang benar. Pada saat peserta didik menirukan, guru menyimak bacaan peserta didik dengan teliti. Ketika ada bacaan yang salah, baik makhraj ataupun tajwidnya, guru mengingatkan dan 


\section{QUALITY}

Volume 6, Nomor 1, 2018: 16-30

membenarkannya. Pemilihan strategi ini dikarenakan adanya perbedaan kemampuan setiap peserta didik. Ada peserta didik yang sudah lancar membaca $A l$ Qur"an ada yang belum lancar membaca Al Qur'an. Agar peserta didik yang belum lancar membaca Al Qur'an bisa mengikuti atau mengimbangi yang sudah lancar membaca Al Qur'an maka seluruh peserta didik membaca ayat demi ayat secara bersama-sama (klasikal).

Pada kelas rendah (kelas 1-3) surat dibaca secara penuh dan berulang-ulang di setiap harinya. Sedangkan di kelas tinggi (kelas 4-6), hafalan dilakukan secara bertahap. Umumnya menggunakan metode one day one ayat. Yakni target hafalan setiap harinya mencapai satu ayat. Awalnya dibaca berulang-ulang, setelah hafal diulang tanpa membaca buku secara berulang-ulang. Pada hari berikutnya ditambah satu ayat dengan mengulang ayat pada hari sebelumnya. Namun metode one day one ayat tidak selalu diterapkan pada setiap harinya karena setiap ayat dalam surat tersebut memiliki panjang dan pendek yang berbeda. Ketika ayatnya pendek, maka dalam sehari tidak hanya satu ayat yang dihafalkan, tetapi beberapa ayat. Hal itu disesuaikan dengan kemampuan peserta didik dan waktu yang tersisa. Setelah satu surat penuh telah dihafalkan, guru menyampaikan pesan tersirat dari surat tersebut.

Pada saat pelaksanaan hafalan, tentu kondisi peserta didik sangat bervariasi. Ada peserta didik yang antusias mengikuti proses hafalan dari awal hingga akhir, ada yang berbicara dengan temannya, ada yang belum hafal dan menirukan temantemannya dengan ragu, ada yang menjahili temannya. Berbagai perilaku yang muncul dari peserta didik tersebut masih bisa diatasi dengan keseriusan guru dalam menjalankan tugas dan tanggung jawabnya. Misalnya dengan pengawasan dan pendampingan penuh, berjalan mengelilingi peserta didik, dan mengingatkan peserta didik yang gaduh. Untuk mengetahui dan memastikan hafalan peserta didik, guru melakukan penilaian pada tiap semester dengan meminta peserta didik maju satu per satu. Selain itu, terkadang guru juga sesekali mengetes hafalan peserta didik usai proses hafalan berlangsung

\section{B. Penanaman Karakter Islami di SD I Nurul Qur'an Semarang}

Langkah-langkah pendidikan karakter Islami dalam pembelajaran Tahfidz Al Qur'an di SD I Nurul Qur'an Semarang sudah berjalan dengan sangat baik dan ini di 


\section{QUALITY}

Volume 6, Nomor 1, 2018: 16-30

tandai dengan dilibatkanya semua warga sekolah di dalam merencanakan dan melaksanakanya. Langkah-langkah pendidikan karakter Islami terbagi kepada 2 bagian yaitu langkah-langkah penanaman pendidikan karakter Islami yang di tempuh sekolah, meliputi: Membentuk Tim TTQ, membuat panduan pengajaran, mengadakan sosialisasi panduan pengajaran TTQ, mengadakan pelatihan Guru TTQ, menyiapkan sarana prasarana, mengadakan pengawasan pendidikan karakter Islami dalam pembelajaran Tahfidz Al Qur'an. dan langkah-langkah pendidikan karakter Islami yang di tempuh oleh guru meliputi: Membedah buku panduan pengajaran TTQ, menetapkan metode dan strategi pengajaran TTQ, menetapkan koordinator jenjang dan memasukan karakter religius, bersih, disiplin, istiqamah dan sabar dalam pembelajaran.

Implementasi pendidikan karakter Islami dalam pembelajaran Tahfidz Al Qur'an di SD I Nurul Qur'an Semarang sudah berjalan dengan baik, untuk menanamkan ke 5 karakter Islami (Religius, Bersih, Istiqomah, Disiplin, dan Sabar.) di tempuh berbagai cara mulai dari keteladanan, pembiasaan, pembentukan lingkungan yang di mulai dari proses baris berbaris di depan kelas, sebelum shalat zhuhur di kelas untuk siswi dan di masjid untuk siswa, dan pada setiap pembelajaran Tahfidz Al Qur'an di kelas/tempat belajar masing-masing. Karakter Islami di terapkan pada : Berwudhu sebelum belajar Tahfidz Al Qur'an, berdo'a sebelum dan sesudah belajar Tahfidz Al Qur'an, berdo'a setiap habis shalat, shalat 5 waktu, Qiyamulail, puasa senin kamis dan meminta do'a khusus kepada orang tua. Karakter bersih diterapkan pada: bersih lahiriah (berwudhu sebelum belajar, pakaian bersih, tempat belajar bersih dan alat yang digunakan dalam belajar harus bersih. Karakter disiplin diterapkan pada: kedisiplinan berdo'a sebelum dan sesudah belajar, kedisiplinan datang di tempat belajar tepat waktu, kedisiplinan mengulang hafalanya, dan kedisiplinan menyetor hafalan. Karakter istiqamah diterapkan pada : keistiqamahan siswa dalam menghafal dan keistiqamahan siswa dalam menyetor hafalan. Karakter sabar diterapkan pada: kesabaran siswa dalam mengulang hafalan, kesabaran siswa dalam siswa dalam menyetor hafalan, kesabaran siswa dalam belajar dan kesabaran siswa dalam ulangan.

Jurnal yang berjudul Pendidikan Karakter Berbasis Nilai-Nilai Religius karya Siswanto menyatakan bahwa karakter religius adalah karakter yang mengacu pada nilai-nilai dasar yang terdapat dalam agama. Setelah peneliti melakukan analisis data, karakter Islami peserta didik SD I Nurul Qur'an Semarang sesuai dengan teori tersebut yakni mengacu pada nilai-nilai dasar dalam agama Islam. Berdasarkan data yang 


\section{QUALITY}

\section{Volume 6, Nomor 1, 2018: 16-30}

peneliti peroleh dari informan, mereka mengemukakan bahwa Peserta didik SD I Nurul Qur'an Semarang memiliki karakter Islami yang cukup bagus. Karakter Islami tersebut meliputi sopan santun dengan guru serta tidak membantah gurunya, giat beribadah seperti wudlu sebelum pembelajaran di mulai, salat berjamaah di Masjid, membaca $A l$ Qu'an, dan berdoa sebelum dan sesudah pembelajaran.

Upaya yang dilakukan untuk membentuk karakter Islami peserta didik yakni melalui penerapan model pembentukan karakter yang sesuai dengan Al Qur'an. Buku yang berjudul Pendidikan Karakter Berbasis Al Qur'an karya Ulil Amri Syafri, mengatakan bahwa model pembentukan karakter ini meliputi (1) model perintah atau dalam Islam dikenal dengan al-amr; (2) model larangan, dalam masalah akhlak, bila dilarang untuk mengerjakan sesuatu berarti bisa dimaknai perintah untuk melakukan amalan sebaliknya; (3) model motivasi (targib) sering diartikan dengan kalimat yang menimbulkan keinginan kuat, membawa seorang tergerak untuk melakukan sebuah amalan; (4) model tarhib adalah upaya menakut-nakuti manusia agar menjauhi dan meninggalkan suatu perbuatan. model kisah, kisah yang diungkapkan dalam $A l$ Qur'an ini meliputi berbagai aspek pendidikan yang dibutuhkan manusia, termasuk aspek akhlak; (6) model dialog dan debat, tidak sedikit pembaca yang merasa ikut terlibat langsung dalam model dialog-dialog yang ditampilkan Al Qur'an; (7) model pembiasaan, proses pendidikan yang berkaitan dengan akhlak atau perilaku tanpa diikuti dan didukung adanya praktik dan pembiasaan pada diri, maka pendidikan itu hanya menjadi angan-angan saja karena pembiasaan dalam proses pendidikan sangatlah dibutuhkan; model teladan, pendidik dituntut untuk memiliki kepribadian dan intelektualitas yang baik sesuai dengan Islam sehingga konsep pendidikan yang diajarkan dapat langsung diterjemahkan melalui diri para pendidik.

Tidak hanya karakter Islami, banyak karakter lain yang dapat dihasilkan dari Tahfidz Al Qur'an. Apabila peserta didik dapat menyerap semua kandungan dari materi yang dihafalkan, maka dalam setiap langkahnya akan diiringi hafalan-hafalan tersebut. Sehingga dalam bersikap dan berperilaku, peserta didik akan mengingatingat hafalannya. Secara otomatis, ketika peserta didik telah memahami pesan dari hafalan, karakter-karakter yang lain akan mengikuti. Dengan kata lain, karakter Islami yang diperoleh dari hafalan Tahfidz Al Qur'an ini dapat memunculkan 


\section{QUALITY}

Volume 6, Nomor 1, 2018: 16-30

karakter-karakter lain. Seperti disiplin, kerja keras, gemar membaca, dan lain sebagainya.

\section{Simpulan}

Berdasarkan penelitian yang telah dilakukan, maka dapat diambil kesimpulan bahwa:

Langkah-langkah pendidikan karakter dalam pembelajaran Tahfidz Al Qur'an di SD I Nurul Qur'an Semarang sudah berjalan dengan sangat baik dan ini di tandai dengan dilibatkanya semua warga sekolah di dalam merencanakan dan melaksanakanya. Langkah-langkah pendidikan karakter Islami terbagi kepada 2 bagian yaitu langkah-langkah penanaman pendidikan karakter yang di tempuh sekolah, meliputi: Membentuk Tim TTQ, membuat panduan pengajaran, mengadakan sosialisasi panduan pengajaran TTQ, mengadakan pelatihan Guru TTQ, menyiapkan sarana prasarana, mengadakan pengawasan pendidikan karakter Islami dalam pembelajaran Tahfidz Al Qur'an di SD I Nurul Qur'an Semarang. dan langkah-langkah pendidikan karakter Islami yang di tempuh oleh guru meliputi: Membedah buku panduan pengajaran TTQ, menetapkan metode dan strategi pengajaran TTQ, menetapkan koordinator jenjang dan memasukan karakter religius, bersih, disiplin, istiqamah dan sabar dalam pembelajaran.

Implementasi pendidikan karakter Islami dalam pembelajaran Tahfidz Al Qur'an di SD I Nurul Qur'an Semarang sudah berjalan dengan baik, untuk menanamkan ke 5 karakter (Religius, bersih, istiqomah, disiplin, dan sabar.) di tempuh berbagai cara mulai dari keteladanan, pembiasaan, pembentukan lingkungan yang di mulai dari proses baris berbaris di depan kelas, sebelum shalat zhuhur di kelas untuk siswi dan di masjid untuk siswa di kelas/tempat belajar masing-masing. Karakter Islami di terapkan pada : Berwudhu sebelum belajar Tahfidz Al Qur'an, berdo'a sebelum dan sesudah belajar Tahfidz Al Qur'an, berdo'a setiap habis shalat, shalat 5 waktu, qiyamulail, puasa senin kamis dan meminta do'a khusus kepada orang tua. Karakter bersih diterapkan pada: bersih lahiriah (berwudhu sebelum belajar, pakaian bersih, tempat belajar bersih dan alat yang digunakan dalam belajar harus bersih. Karakter disiplin diterapkan pada: kedisiplinan berdo'a sebelum dan sesudah belajar, 


\section{QUALITY}

Volume 6, Nomor 1, 2018: 16-30

kedisiplinan datang di tempat belajar tepat waktu, kedisiplinan mengulang hafalanya, dan kedisiplinan menyetor hafalan. Karakter istiqamah diterapkan pada :

keistiqamahan siswa dalam menghafal dan keistiqamahan siswa dalam menyetor hafalan. Karakter sabar diterapkan pada: kesabaran siswa dalam mengulang hafalan, kesabaran siswa dalam siswa dalam menyetor hafalan, kesabaran siswa dalam belajar dan kesabaran siswa dalam ulangan. 


\section{Daftar Pustaka}

Al-Qur'an, 2013. Al-Qur'an dan Terjemahnya. Jakarta: Departemen Agama RI. Darus Sunnah.

Aulia, Listya Rani, 2016."Implementasi Nilai Religius dalam Pendidikan Karakter Bagi Peserta Didik di Sekolah Dasar Juara Yogyakarta”, Jurnal Kebijakan Pendidikan Edisi 3 Vol. 5 (2016): 314-323.

Al-Qattan, 2001. Manna Khalil. Studi Ilmu-Ilmu Qur'an. Bogor: Pustaka Litera Antar Nusa.

Abdul Aziz, Abdul Rauf. 2004. Kiat Sukses Menjadi Hafidz Qur'an Da'iyah. Bandung : PT.Syamil Cipta Media.

Akhmad Muhaimin Azzet, 2011. Urgensi Pendidikan Karakter di Indonesia, (Jogjakarta: Ar-Ruzz Media.

Barnawi, M. Arifin. 2013. Strategi \& Kebijakan Pembelajaran Pendidikan Karakter. Jogjakarta: Ar-Ruzz Media.

Furqon, Hidayatullah. 2010. Pendidikan Karakter: Membangun Peradaban Bangsa. Surakarta: Yumna Pusaka.

Ibrahim Bin Ubbu Al-Hasaniy Asy-Syinqithiy. 2017. Rihlah Tahfiz: Metode Pendidikanan Menghafal Al-Qur'an Ala Ulama Syinqith. Kediri: Lirboyo Press.

Listya Rani Aulia, 2016. "Implementasi Nilai Religius dalam Pendidikan Karakter Bagi Peserta Didik di Sekolah Dasar Juara Yogyakarta", Jurnal Kebijakan Pendidikan Edisi 3 Vol. $5: 321$

Nasrudin Razak, 1997. Dienul Islam. Bandung: PT. Al Maarif. 


\section{QUALITY}

Volume 6, Nomor 1, 2018: 16-30

Mustaqim, Muhammad. 2015. "Model Pendidikan Karakter Terintegrasi pada Pembelajaran di Pendidikan Dasar” Elementary Vo. 3 No. 1 : 156-169.

Musyanto, 2016. "Pendidikan Karakter dalam Pembelajaran Tahfiz Al-Qur'an di SDIT IQRA 1 Kota Bengkulu” Jurnal Al-Bahtsu Vol.1 No.1 : 3-15.

Muchlas, Samani, 2011. Konsep dan Model Pendidikan Karakter, Bandung: Remaja Rosdakarya.

Muhammad Fadlillah, Lilif Mualifatu Khorida. 2014. Pendidikan Karakter Anak Usia Dini: Konsep \& Aplikasinya dalam PAUD. Jogjakarta: Ar-Ruzz Media.

Sjarkawi, 2006. Pembentukan Kepribadian Anak; Peran Moral, Intelektual, Emosional, dan Sosial sebagai Wujud Integritas Membangun Jati diri, Jakarta: Bumi Aksara.

Syafaah, Mukaromah, wawancara oleh Shobirin Muhammad. Sekolah Tinggi Agama Negeri Islam Kudus. Tanggal 9 Mei 2017.

Siswanto, 2013. "Pendidikan Karakter Berbasis Nilai-Nilai Religius", Jurnal Tadris Vol. 8 No. 1.

Umar, 2017. "Implementasi Pembelajaran Tahfiz Al-Qur"An di SMP Luqman Al- Hakim", Tadarus: Jurnal Pendidikan Islam Vol. 6, No. 1 : 1-20.

Ulil Amri Syafri, 2012. Pendidikan Karakter Berbasis Al-Qur'an (Jakarta: Rajagrafindo Persada, 125-140.

Zubaedi, 2013. Pendidikan Karakter Melalui Pola Pembelajaran Integralistik, Makalah Seminar Internasional di Pascasarjana IAIN Bengkulu.

Zulfitria, 2017. "Peranan Pembelajaran Tahfiz Al-Qur'an dalam Pendidikan Karakter di Sekolah Dasar", Jurnal Naturalistic Vol.1 No.2 : 125-134 